\title{
Et godt år for hurricanes - en sceson til rekordbøgerne
}

Af Niels Hansen og John Cappelen, DMI

Allerede inden de tre monstre

Katrina, Rita og Wilma slog til mod USA i henholdsvis august, september og oktober, havde sæsonen 2005 sat rekorder. Blandt andet på grund af flere og kraftigere hurricanes i de første - normalt rolige - måneder juni og juli end noget tidligere år.

Sæsonen for tropiske orkaner i Atlanterhavet løber officielt fra 1. juni og frem til 30. november - normalt med størst aktivitet mellem 1 . august og slutningen af oktober. Men i år opstod det sjette system (der navngives med alfabetets sjette bogstav, og som i år hed Franklin) allerede den 22. juli. Aldrig tidligere er F-stormen forekommet så tidligt i sæsonen. Hidtil har det tidligste for storm nummer seks været den 3 . august, og det var tilbage i 1993.

\section{Rekordår}

Sæsonen 2005 oplevede også kraftige systemer allerede før Katrina; selvom det antageligt er den, alle vil mindes i årene fremover. Blandt andet slog Emily til mod Mexico i to omgange midt $\mathrm{i}$ juli med vindhastigheder på over $200 \mathrm{~km} / \mathrm{t}(56 \mathrm{~m} / \mathrm{s})$.

To øvrige rekorder blev til kort efter hinanden sidst i oktober. Først målte amerikanske hurricane-hunterfly det laveste centertryk i en hurricane nogensinde, da Wilma nåede ned på $882 \mathrm{hPa}$ (hektopascal), og få dage senere opstod sæsonens 22. tropiske stormsystem i Atlanten (Alpha), hvilket er ét flere end den hidtidige rekord på 21 fra 1933 (se inddelinger af tropiske storme og orkaner i tabellen nederst på næste side).

\section{Katrina}

I starten af august valgte den amerikanske vejrtjeneste NOAA og orkanvarslingscentret NHC at opgradere deres allerede ekstreme varsel for hurricanesæsonen 2005. Det skulle blive til $i$ alt mellem 18 og 21 navngivne storme fra juni til oktober 2005 (et lavtryk navngives, når middelvinden når $63 \mathrm{~km} / \mathrm{t}$ eller $17,5 \mathrm{~m} / \mathrm{s}$ ).

Af de navngivne storme skulle ni til elleve nå hurricanestyrke, og et sted mellem fem og syv af disse blive kraftige hurricanes (det vil sige over kategori 3).

Sidst i august blev Hurricane Katrina så

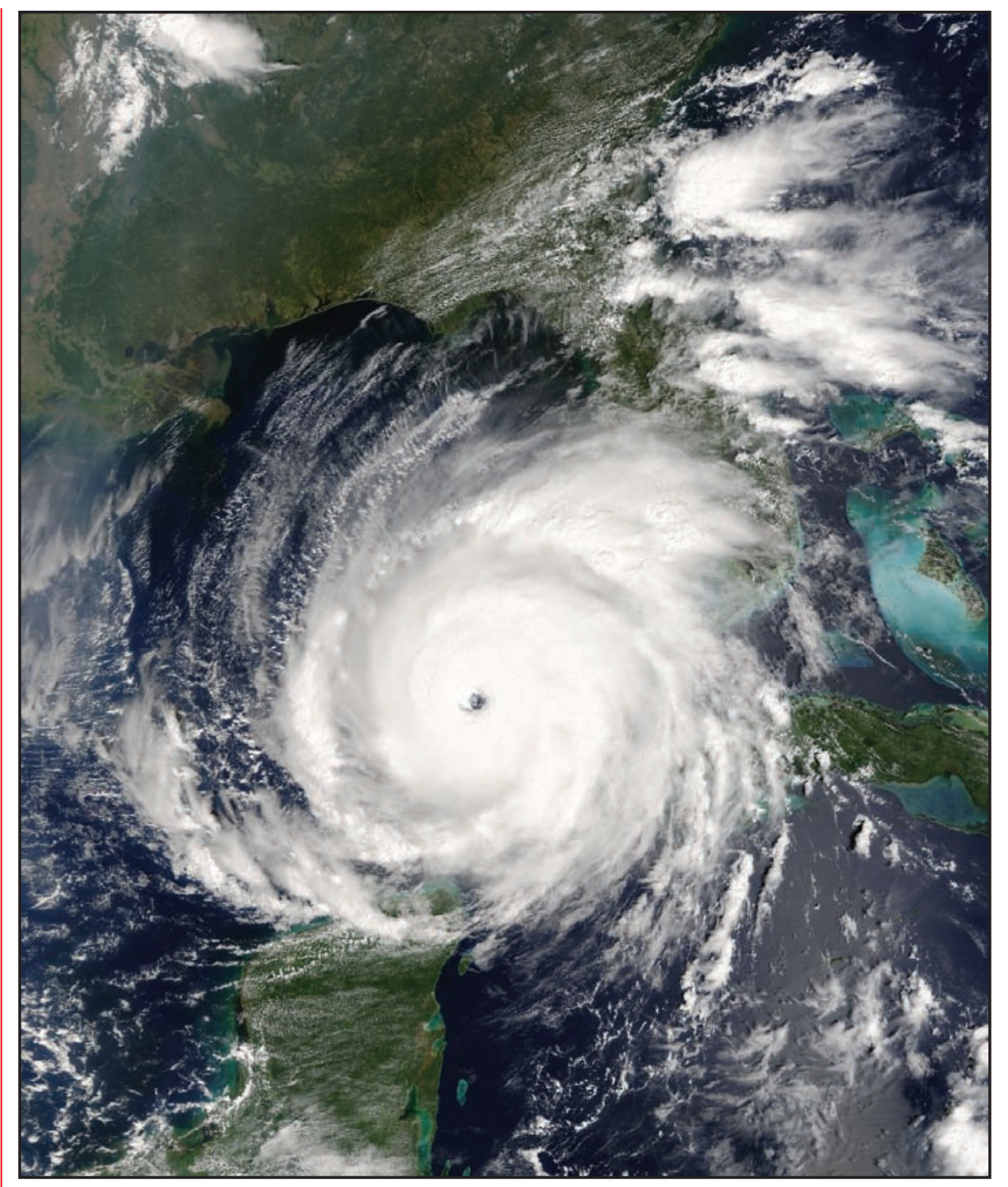

Rita som en kategori 5 hurricane i Den Mexicanske Golf den 21. september 2005. Rita fulgte på dette tidspunkt stadig samme bane som Katrina $3^{1 / 2}$ uge tidligere, men endte som bekendt med at gå i land langt vest for New Orleans. (Foto: MODIS-instrumentet på NASA's Aqua-satellit)

født som tropisk lavtryk nummer 12 og nåede en styrke, der gav den navn den 24. august. I løbet af torsdag den 25. august havde Katrina samlet energi nok til at blive en hurricane med vindstød på op til $148 \mathrm{~km} / \mathrm{t}$ $(41 \mathrm{~m} / \mathrm{s})$.

Det var også torsdag den 25. august, at Katrina gjorde landgang første gang i det sydlige Florida. Katrina gjorde entré som en kategori 1-hurricane og oversvømmede gader og huse som resultat af den massive nedbør.

Da Katrina igen forlod Florida, kom systemet ud over den Mexicanske Golf. Det meget varme vand gav fornyet styrke, og
Katrina nåede helt op i kategori 5 inden næste landgang i Louisiana lidt øst for New Orleans, hvor systemet dog igen var "nede" som en kategori 4-hurricane.

Flere mindre byer langs kysten blev stort set fjernet fra landkortet, men opmærksomheden rettede sig mod musikbyen New

Orleans, der havde alle ingredienserne til en katastrofe.

Store dele af New Orleans ligger nemlig nær eller under vandniveauet i både havbugten mod øst, søen Lake Pontchartrain mod nord og Mississippifloden, der løber gennem selve byen. Godt nok er der bygget omfattende diger, men de er gamle, dårligt 


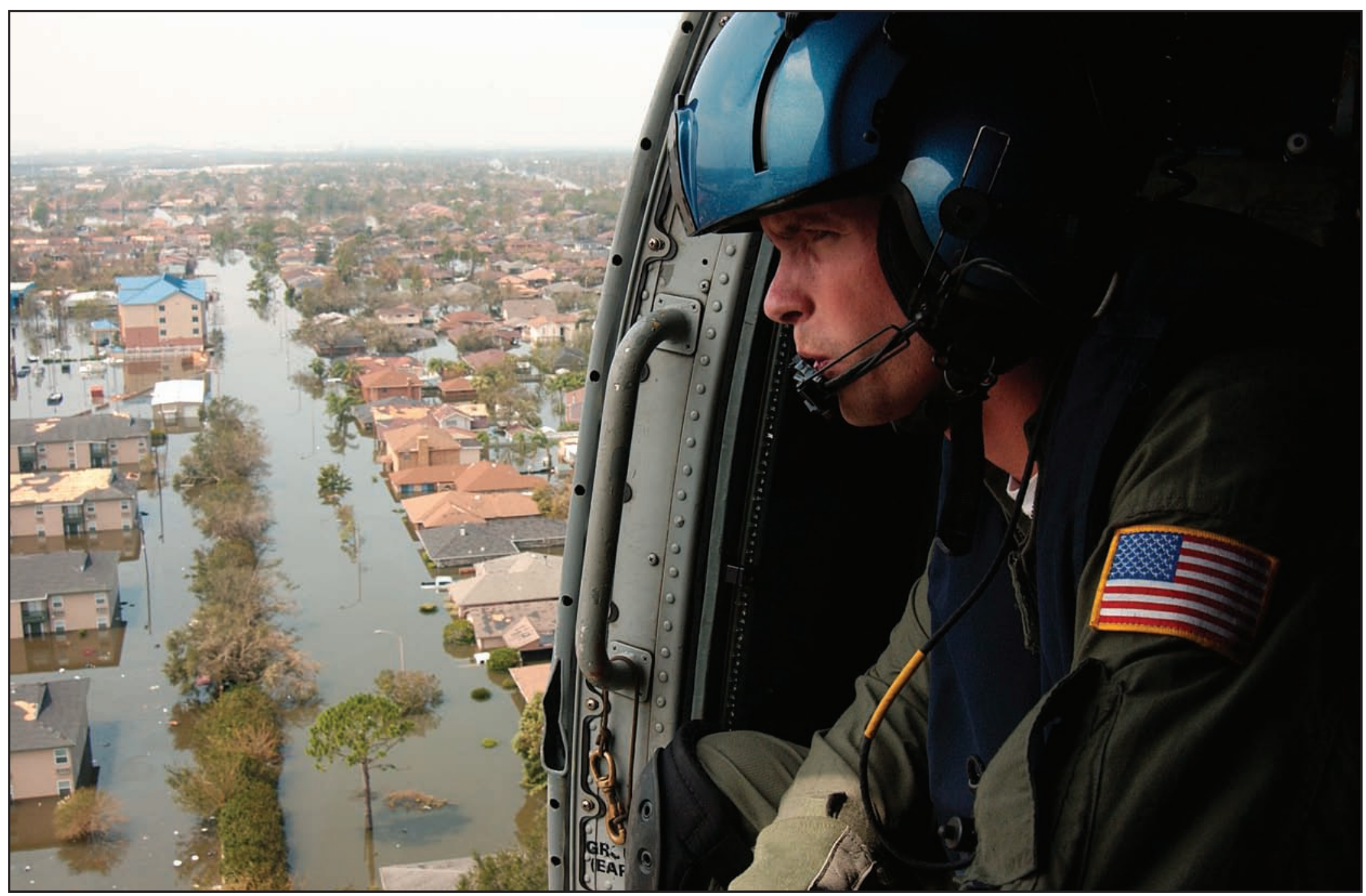

Oversergent af 2. grad i den amerikanske kystbevogtning Shawn Beaty spejder efter overlevende i New Orleans dagen efter Hurricane Katrina. Bemæerk, hvordan vandet, der hovedsageligt kom fra søen Lake Pontchartrain, står meterhøjt og næesten når tagskcegget på mange etplanshuse. (Foto: U.S. Coast Guard/Oversergent af 2. grad Nyxo Lyno Cangemi)

vedligeholdt og slet ikke dimensionerede til en fuldtræffer fra en kategori 4- eller 5hurricane.

Ud over de geografiske og infrastrukturmæssige problemer så er New Orleans også en af de socialt mest sårbare større byer i USA. Byen ligger i bund, hvad angår uddannelsesniveau og økonomisk formåen, hvilket tilsammen giver lav mobilitet. Det medførte, at en forholdsvis stor del af indbyggerne enten ikke kunne eller ikke ville forlade byen itide.

Resultatet kender de fleste af os fra mediernes intensive dækning. Over 1.200 mennesker omkom og mange, mange flere har intet at vende tilbage til - noget man normalt kun ser i forbindelse med naturkatastrofer i den tredje verden.

\section{Saffir-Simpson-skalaen}

Tropiske storme og orkaner bliver kategoriseret efter barometertrykket i stormens centrum og vindhastigheden i den roterende bevægelse.

\begin{tabular}{|l|c|c|c|c|c|} 
Type & Kategori & $\begin{array}{c}\text { Centertryk } \\
{[\mathrm{hPa}]}\end{array}$ & $\begin{array}{c}\text { Vindhastig- } \\
\text { hed [m/s] }\end{array}$ & $\begin{array}{c}\text { Stormbølge- } \\
\text { højde [m] }\end{array}$ & $\begin{array}{c}\text { Potentiel "kendt" } \\
\text { skade }\end{array}$ \\
\hline Tropisk lavtryk & TD & - & $<17,5$ & - & - \\
\hline Tropisk storm & TS & - & $17,5-32,4$ & - & - \\
\hline Tropisk orkan & 1 & $>980$ & $32,5-42,4$ & ca. 1,5 & $\begin{array}{c}\text { Nogen skader på krat og træer og } \\
\text { ikke fastgjorte beboelsesvogne }\end{array}$ \\
\hline Tropisk orkan & 2 & $965-980$ & $42,5-49,9$ & ca. 2-2,5 & $\begin{array}{c}\text { Store skader på beboelsesvogne } \\
\text { samt hustage; træer vælter }\end{array}$ \\
\hline Tropisk orkan & 3 & $945-965$ & $50,0-57,9$ & ca. 2,5-4 & $\begin{array}{c}\text { Beboelsesvogne fuldstændigt } \\
\text { ødelagt; store træer vælter: små } \\
\text { bygninger skadet }\end{array}$ \\
\hline Tropisk orkan & 4 & $920-945$ & $58,0-68,9$ & ca. 4-5,5 & $\begin{array}{c}\text { Beboelsesvogne fuldstændigt } \\
\text { ødelagt; underetage af huse nær } \\
\text { kysten potentielt oversvømmet }\end{array}$ \\
\hline Tropisk orkan & 5 & $<920$ & $>69,0$ & $>5,5$ & $\begin{array}{c}\text { Omfattende ødelæggelser på } \\
\text { huse, industribygninger; små huse } \\
\text { blæser væk; underetage af } \\
\text { bygninger inden for 500 meter af } \\
\text { kysten og mindre end 4,5 meter } \\
\text { over msl. bliver ødelagt }\end{array}$ \\
\hline
\end{tabular}

Et par uger efter Katrina var den for øvrigt rigtig gal igen - og Hurricane Rita gjorde sig da også stort set øjeblikkeligt uheldigt bemærket ved i begyndelsen at følge Katrinas bane gennem Floridastrædet og ud i Den Mexicanske Golf. Rita endte dog med at ramme lige øst for grænsen mellem Louisiana og Texas som en kategori 3.

Det mest bemærkelsesværdige ved Rita, 
Hovedelementerne $i$ en tropisk orkan. De kraftigste vinde findes i øjemuren og det laveste luftryk $i$ selve øjet. Regnbåndene og den kraftige nedbør strcekker sig langt ud fra centrum af systemet. (Grafik: $U V H$ Modificeret efter "Gyldendals store bog om vejret". Gyldendal, 1999)

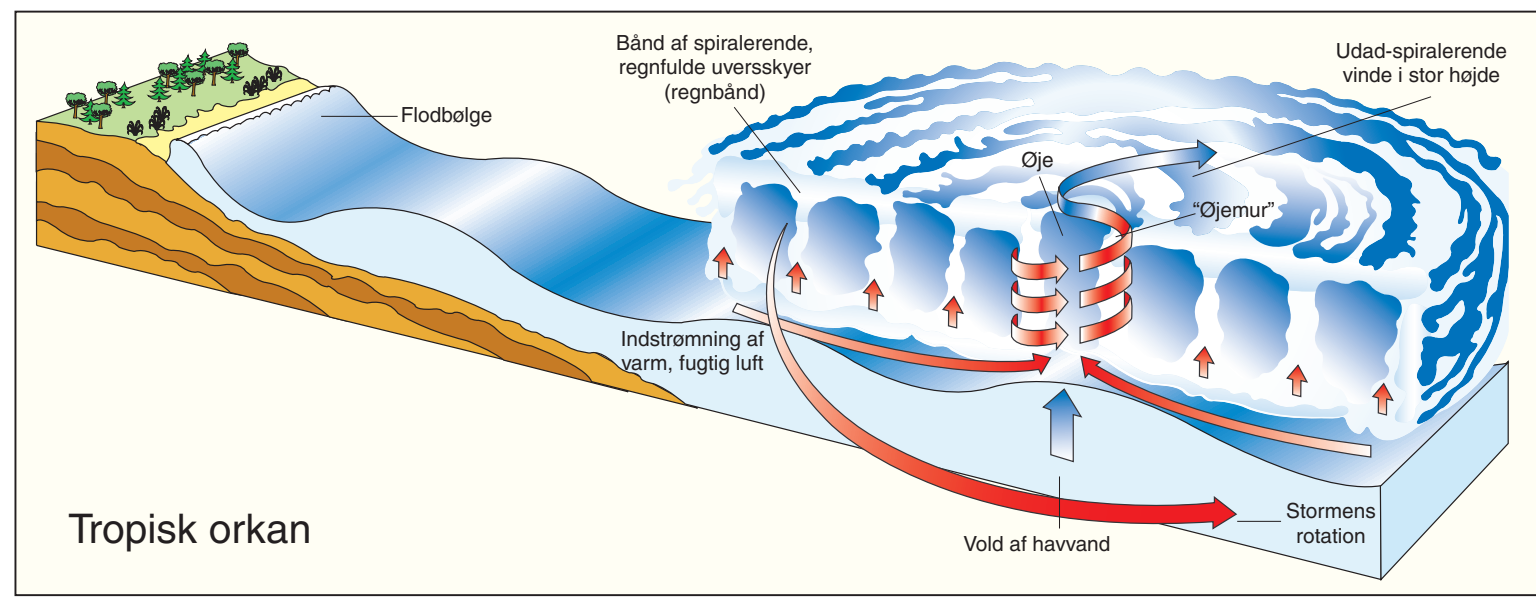

var den voldsomme reaktion, den medførte USA med hensyn til evakueringer og beredskab på grund af Katrinas hærgen få uger tidligere. Flere end 100.000 mennesker blev jaget ud af kystbyerne, og en ikke ubetydelig del af dem, der mistede livet i forbindelse med Rita, omkom under de tumultagtige scener på hovedvejene ud af Houston. Også uden for USA var interessen enorm. Aldrig har et vejrsystem været fulgt så tæt i medierne, som Rita blev det.

I New Orleans beordrede myndighederne for øvrigt igen indbyggerne evakueret, fordi de frygtede, at de skrøbelige, lappede diger ville bryde sammen endnu en gang. Det viste sig at holde stik, til trods for at Rita gik i land flere hundrede kilometer mod vest.

\section{Hurricanes - et blik bag kulisserne} Hurricanes tilhører klassen af tropiske cykloner. Andre steder i verden hedder den samme type systemer $\mathrm{fx}$ tyfoner. Tropiske cykloner betegner lavtrykssystemer med et tværsnit på op til ca. 500 kilometer uden egentlige fronter over et tropisk eller subtropisk havområde.

\section{Fase 1: Tropisk forstyrrelse}

Det hele starter som en "forstyrrelse" - en samling af tordenvejr i en ustabil atmosfære over et varmt hav (normalt mindst $26,5^{\circ} \mathrm{C}$ ) - et sted i troperne eller subtroperne.

Hovedenergikilden til tropiske systemer af denne art stammer simpelthen fra varme og fugtighed tilført via fordampning fra havoverfladen. Der er ingen organisation, og man kan dårligt se forstyrrelsen i vind- eller trykfeltet. Hvis forstyrrelsen får lov at leve i mere end 24 timer, kan det udvikle sig...

\section{Fase 2: Tropisk lavtryk}

Når først en gruppe af tordenvejr har været samlet længe nok under de rette atmosfæriske betingelser, kan de organisere sig og blive til et tropisk lavtryk.

Bestemmende for det er, at der forekommer de første tegn på organiseret cirkulation i centret af tordenstormene, og at trykket falder. Samtidig vil vinden nær centret blæse fra 36 til $63 \mathrm{~km} / \mathrm{t}$ (10 til 17,5 m/s)

Den afbøjende kraft, corioliskraften, der påvirker alle ting, der bevæger sig på den roterende Jord - også vinden, er vigtig her. Den sørger for, at det lave lufttryk i den begyndende rotation i det tropiske lavtryk kan vedligeholdes, da vindene så populært sagt ikke bevæger sig lige ind og fylder lavtrykket op.

\section{Fase 3: Tropisk storm}

Når et tropisk lavtryk har udviklet sig så maksimumvindene ligger mellem 63 og 117,7 $\mathrm{km} / \mathrm{t}(17,5 \mathrm{og} 32,7 \mathrm{~m} / \mathrm{s})$, betegnes systemet som en tropisk storm. Stormen er nu mere organiseret og begynder at blive mere cirkulær i sin form, og rotationen er åbenbar. Be-

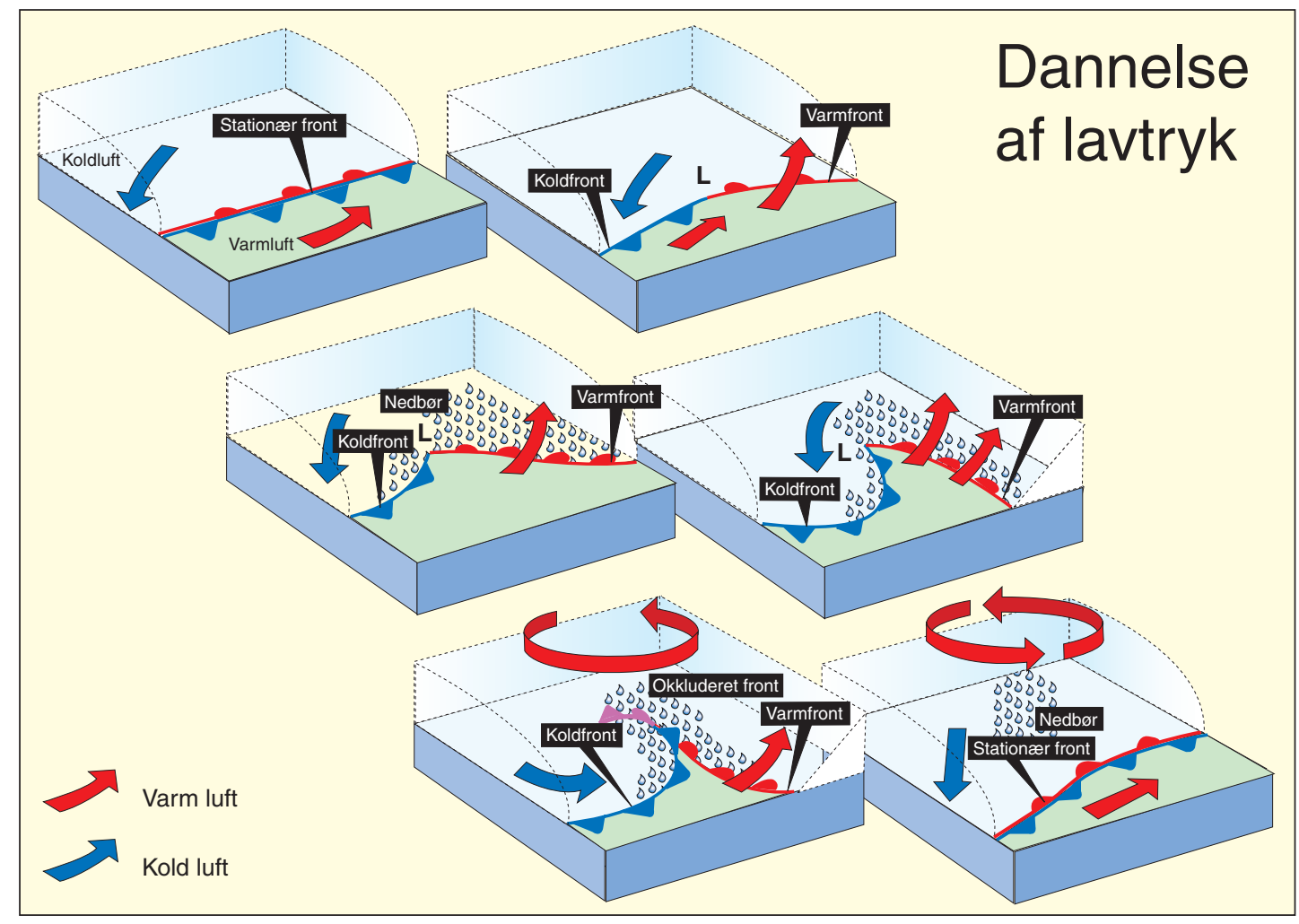

Udviklingen af et lavtryk pa vores breddegrader. Den kolde luft fra nord er vist med blå farve og den varme luft med rødt. Pilene angiver de vigtigste luftstrømme, og farven viser dens oprindelse. Lavtrykket er markeret med et L. (Grafik: Modificeret af UVH efter DMI, anvendt i 3/04) 
mærk, at storm på vores breddegrader (ifølge Beaufort-skalaen) først starter ved $24,5 \mathrm{~m} / \mathrm{s}$ og ikke allerede ved $17,5 \mathrm{~m} / \mathrm{s}$, som det gælder for tropiske systemer.

\section{Fase 4: Tropisk orkan}

Med et fortsat fald i overfladetrykket - og når middelvinden (målt over 10 minutter) overstiger $117,7 \mathrm{~km} / \mathrm{t}(32,7 \mathrm{~m} / \mathrm{s})$ - bliver systemet til en tropisk orkan. Rotationen omkring centret er nu meget tydelig.

En karakteristisk ting ved en tropisk cyklon er det mørke område, der tit findes i centret. Dette kaldes øjet. Omkring øjet findes de mest intense vinde og den kraftigste regn, i det man kalder øjemuren. Ellers ses skyerne og nedbøren at være organiseret i spiralerende bånd kaldet regnbånd.

Forløbet fra den første forstyrrelse til den fuldvoksne tropiske cyklon af orkanstyrke tager i snit to til fire døgn, selvom det kan variere en del. Levetiden for et system varierer også meget, men normalt lever de $\mathrm{i}$ to til tre uger, inden de dør. Det sker som regel, når de mister kontakt til det varme vand, enten fordi systemet går i land eller kommer for langt væk fra Ækvator.

\section{Danske orkaner}

Ordet hurricane er oprindeligt det samme udtryk som ordet orkan. Begge stammer de fra det spanske huracán, der blot betyder "kraftig vind". Men en hurricane og en dansk orkan er i bund og grund to forskellige fænomener.

De danske orkaner (og storme) opstår

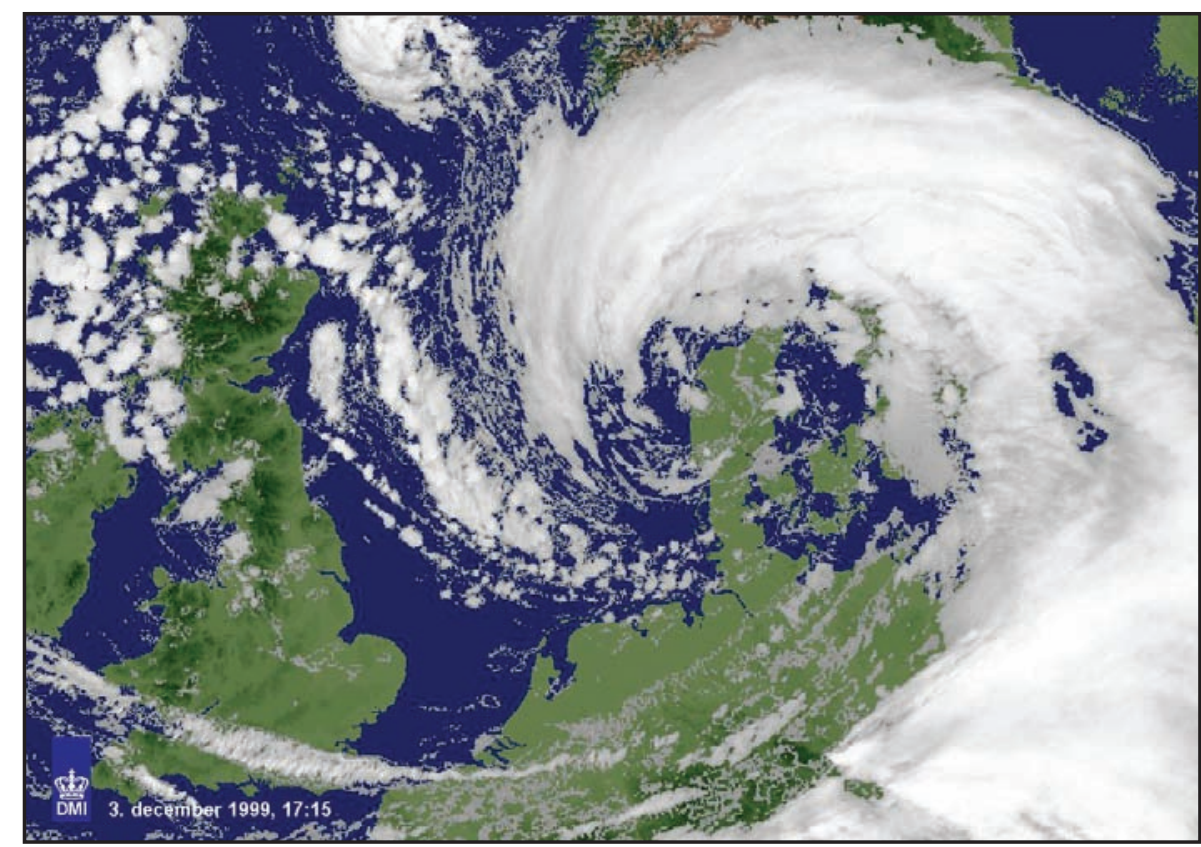

Orkan over Danmark den 3. december 1999 klokken 18:15 (tidsangivelsen på billedet er UTC, som er én time efter dansk normaltid). I middelvinden nåede vi op på, hvad der svarer til kategori 1 på skalaen for tropiske orkaner (38 m/s på Rømø klokken ca. 18:00 dansk tid). (Foto: NOAA/DMI)

normalt langs polarfronten og lever hovedsageligt af temperaturforskellen mellem luftmasser. Jo større forskel - jo kraftigere har lavtryksudviklingen mulighed for at blive.

Det betyder, at vi oftest får storme og orkaner i efteråret og i første halvdel af vinteren. Her er temperaturforskellene størst mellem den endnu varme sydlige del af den nordlige halvkugle og den relativt koldenord- lige del af halvkuglen. Det kommer fx til udtryk, når kold arktisk luft fra Canada strømmer ud over den varme Golfstrøm.

Forskelle mellem luftmasser er ikke en energikilde, der kan sammenlignes med varmt havvand, og lavtryksudviklinger hos os når da heller ikke op på den ødelæggende kraft, vi ser i tropiske cykloner.

Vi kommer altså aldrig til at opleve en

\section{Tropiske orkaner kan ikke stoppes}

Kraft som 33 atombomber

Atombomben, der ramte Hiroshima, havde en kraft, der svarer til 15.000 tons TNT. En tropisk orkan som Rita eller Katrina udløser en energi, der svarer til 33 Hiroshimabomber-i minuttet.

Alene derfor kan orkaner ikke stoppes med menneskekraft: De rummer ufattelige mængder af energi, og der skal tilsvarende mængder af energi til for at påvirke dem.

For hver dag en større orkan lever, udløser den ifølge det amerikanske orkanovervågningscenter NHC mere end halvanden gang så meget energi som verdens samlede lagre af atomvåben tilsammen.

Rent bortset fra, at forureningen fra et atombombardement ville blive spredt med orkankraft, hvis man rent faktisk besluttede at forsøge at bombe en orkan væk fra havets overflade, så er der et andet problem:

\section{Orkaner er lavtryk}

Trykket i midten af en orkan er betydeligt lavere end det omgivende tryk, og jo lavere orkanens tryk er, jo værre er den.

Hvis man fyrede en atombombe af i midten på orkanen, ville man bare forværre lavtrykket. Derfor skal energien udløses uden om orkanen og 'presse den sammen', hvis det skal have en nogenlunde fornuftig effekt.

Alternativt kunne man løfte trykket i midten af orkanen ved at smide ekstra luft ned i øjet på orkanen. For at ændre en kategori 5-orkan som Katrina til en kategori-2 orkan - som svarer til den værste, der har ramt Danmark - skal der smides 500 millioner ton ekstra luft ind i orkanens midte.

"Det er vanskeligt at forestille sig en praktisk måde at flytte rundt på så meget luft”, konstaterer orkan-overvågningscenteret NHC tørt.

\section{Påvirkning næppe mulig}

Ved DMI er forskningsleder Leif Laursen helt enig. "Påvirkning af konkrete orkaner er ikke mulig og bliver det formentlig næppe i dette århundrede”, siger han.

Netop fordi energimængderne i orkaner er så store, giver det heller ikke mening at forsøge at angribe orkanerne, før de har vokset sig stærke. Selv 10 procent af en orkanstyrke er langt mere, end det er menneskeligt muligt at håndtere eller påvirke.

Man har i flere omgange i USA foretaget forsøg med at nedkaste bl.a. tøris i orkaner for at mindske deres styrke. I 40'erne og 50'erne skete det i forbindelse med Project Cirrus, i 60'erne og 70'erne foregik det under forsøget Project Stormfury. Det kom der ikke nogle brugbare konklusioner ud af.

"Og skulle det endelig blive muligt at påvirke vejret på større skala, så vil effekten sprede sig som ringe i vandet $\mathrm{i}$ jordens globale vejrsystem”, fastslår Leif Laursen. "Får man regn til at falde ét sted, så udløser man tørke et andet”, slutter han. Journalist Bo Elkjær, Ekstra Bladet, Skipper@eb.dk 


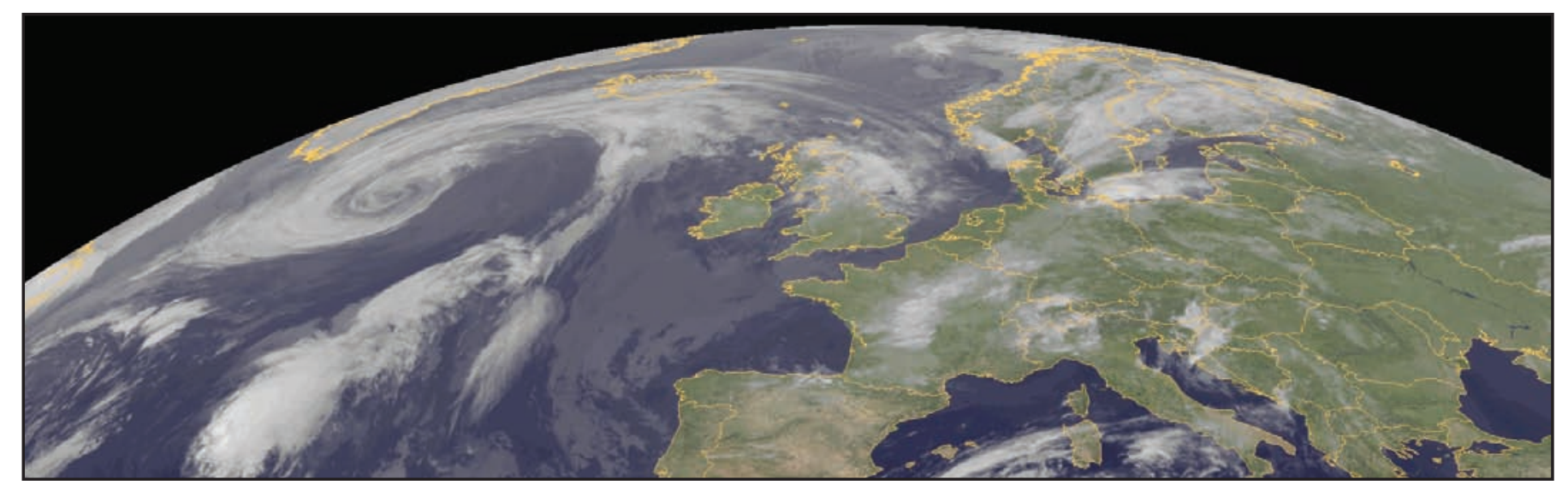

Den tidligere tropiske orkan, Maria, som stormlavtryk (skyspiralen til venstre) i det nordlige Atlanterhav. (Foto: METEOSAT-8 EUMETSAT)

egentlig hurricane i Danmark med de nedbørmængder og de vindhastigheder, der var på banen under fx Katrina og Rita.

Århundredes orkan herhjemme den 3. december 1999 var en lille orkan med ca. 140 km/t (38 m/s), som det højeste målte gennemsnit over ti minutter. Til sammenligning var fx Katrina oppe på det dobbelte i middelvind, mens den var en kategori 5hurricane over Den Mexicanske Golf.

\section{En hurricane på langfart}

Men interessant nok kan vi faktisk få resterne af hurricanes forbi vores del af verden - dog i svækket form. Det er ikke så ofte, det sker, for normalt dør systemet under passagen af højtryksbæltet ca. $30^{\circ}$ nord for Ækvator. Hurricane Maria viste dog i starten af september, hvordan den slags skal gøres.

Maria startede sin tilværelse i Atlanten i slutningen af august 2005 som et kompleks af tordenvejr, der langsomt bevægede sig nordover uden på noget tidspunkt at gå i land.

Undervejs blev Maria intensiveret til en egentlig hurricane og var på et tidspunkt oppe i kategori 3 med et centertryk på 960 hPa og vinde i den roterende bevægelse på over $50 \mathrm{~m} / \mathrm{s}(180 \mathrm{~km} / \mathrm{t})$.
Da Maria kom tilstrækkeligt langt mod nord, forsvandt hovedenergikilden-det varme havvand. Selve lavtrykket levede dog videre som et extratropisk system. Extratropisk betyder egentlig blot “uden for troperne”.

Kolde og varme luftmasser på vores breddegrader blevblandet ind i rotationen, og energien til videreudviklingen kom hovedsageligt fra temperaturforskellen mellem luftmasserne, mens systemet bevægede sig østover. Som det sker, når luftmasser med forskellige karakteristika bliver indblandet, dannes der fronter - en varmfront og en koldfront.

Efter en lang tur først mod nord og så mod øst ramte Maria Norge den 14. september som et stormlavtryk. I forbindelse med Marias landgang i Vestnorge oplevede flere kystbyer meget store nedbørmængder. Blandt andet fik netop Bergen-området over 110 millimeter - eller 11 gulvspande vand pr. kvadratmeter - i løbet af natten, hvilket udløste flere fjeldskred, der kostede mindst én person livet.

\section{En helt usædvanelig sæson}

Det har altså været en helt usædvanlig sæson for hurricanes - tropiske orkaner i Atlanten. Udover de mange, tidlige, kraftige, uddybede og voldsomt omtalte som Katrina, Rita og Wilma har vi haft endnu et par pudsige hændelser, der gør 2005 til noget helt specielt.

Blandt andet gik et tropisk system for første gang nogensinde direkte $\mathrm{i}$ land $\mathrm{i}$ Europa uden en tur forbi Nordamerika på vejen. Det var Vince, som i starten af oktober blev dannet ud for Afrikas vestkyst og ramte Den Iberiske Halvø - dog uden at gøre større skade. Vince blev for øvrigt dannet over havvand, der kun var ca. $23{ }^{\circ} \mathrm{C}$ varmt og hamrede dermed en pæl igennem den forudsætning, at tropiske cykloner kræver over $26,5^{\circ} \mathrm{C}$ under bugen.

Endnu en rekord blev for øvrigt slået, netop som det sidste punktum skulle sættes i denne artikel. Den tropiske storm Beta nåede orkan-styrke og blev derved sæsonens 13. egentlige hurricane. Det betyder, at rekorden fra 1969 for flest systemer, med over $32,7 \mathrm{~m} / \mathrm{s}$ i middelvind, også er slået... 